\title{
The Amsterdam Concertgebouw Orchestra: Guardian of Symphonic Music
}

\author{
Bert Koopman
}

\section{An Institution Under Pressure}

The Concertgebouw Orchestra performs symphonic music at the highest level and across a broad spectrum of canonical and avant-garde orchestral music. The orchestra has developed a distinctive sound, conserves specific orchestral genres (passion music and late Romantic music) while developing a hitherto unprecedented stylistic flexibility through covering classical, twentieth-century, contemporary music and mastery of both the Germanic and the French schools. It delivers the magic of live concerts, creating a sense of the ephemeral. The Orchestra performs timeless works of art, keeping the canon of classical music alive for the next generation. For these reasons, the long-serving (and late) chief conductor, Mariss Jansons, spoke of the 'universal orchestra'.

In the fall of 2019, things were in disarray. Only two years after joining the orchestra, chief conductor Daniele Gatti had been forced to step down following allegations of 'inappropriate behavior'. After a successful 11year run, Managing Director Jan Raes was about to leave the orchestra, just months after both the chairman and the treasurer of the Foundation

B. Koopman $(\bowtie)$

Bergen, The Netherlands

(C) The Author(s) 2021

A. Boin et al. (eds.), Guardians of Public Value, https://doi.org/10.1007/978-3-030-51701-4_7 
board had completed their terms in office. Adding to the exodus, Artistic Director Joel Fried announced his retirement, taking effect in 2020.

This major succession challenge at the top came at a time when the orchestra was confronted with the pressures of a new Zeitgeist. A considerable part of its audience was ageing, but a new generation of listeners remained conspicuously absent. The solemnity of the old concert hall and the classical repertoire no longer seemed attractive to young art lovers. Government funding was under pressure as well. In 2017, the influential Dutch Council for the Arts chastised government funders for their bias towards elite pastimes such as classical music and opera. The Council advocated a less elitist funding policy that pays more attention to contemporary music such as hip hop, $\mathrm{R} \& \mathrm{~B}$, dance and electronic music.

The Concertgebouw Orchestra depends almost half of its annual budget-around 29 million Euro-on public money. Without annual subsidies, the Concertgebouw Orchestra cannot survive. Appealing to everlasting cultural values will not suffice in a neoliberal climate. Frustratingly, traditional audiences continue to age and the influx of young people is stagnating. Most youngsters do not seem to buy the notion that classical music is that interesting (Van Putten 2016). Performing a 'museum' function is not enough. The Orchestra has to renew the old canon, adding new classics and reworking accepted ones to remain attractive to an audience that has many entertainment choices.

That is exactly what the Orchestra has tried to do. The Orchestra continually seeks to renew itself, while staying true to its identity as a cultural carrier. It has created partnerships with other cultural organizations such as museums and theatres. It has designed new forms of presentation, such as short late-night concerts for 'yuppies' without intermission and followed by cocktails. The Orchestra's value proposition has been clear and consistent: preserving a cultural heritage for new generations, while providing a platform for the works of contemporary innovators of orchestral music.

Yet behind the scenes, the ride to stay on top of its game has been a rocky one. In its long existence, the Concertgebouw Orchestra has faced a crisis of sorts nearly every decade or so, often revolving around conflicts between artistic and business interests. The Orchestra has survived each and every one of these crises. With the Gatti case-a rare Me-Too eruption on the Dutch classical music scene-the Orchestra weathered yet another storm. Sponsors, donors and the audience remained fiercely loyal to the orchestra proving itself a 'strong brand' that elicits robust support 
at a time when it could easily have become vulnerable. Over the years, it has demonstrated an enduring vitality in the face of recurrent turbulence.

The Orchestra is more than a group of top musicians, excelling on international stages. The Concertgebouw Orchestra provides a sense of identity to a city and its urban elites. Influential patrons have traditionally supported the institution with their money and political acumen. The nineteenth-century founders of the Concertgebouw building and the Concertgebouw Orchestra were members of the urban aristocracy who wanted to provide allure to the city of Amsterdam, while rubbing themselves into that newfound allure. They wanted to be identified with a majestic concert hall and the elevated practice of symphonic music. To this day, the concert hall and the orchestra both have a robust appeal to a select group of wealthy sponsors and corporate donors, including some of the Netherlands' most prestigious corporations.

How did the orchestra evolve into an institution, defined here as an organizational form that reliably performs a societal task or function in a highly valued way? This chapter investigates how the Concertgebouw Orchestra learned to navigate two sets of colliding forces and how that has shaped its character. One such force was organizational in character and pertains to the complex relation between the Concertgebouw building and the Concertgebouw orchestra. The second source of turbulence has been the tension between artistic and commercial visions. These two forces continually test the relationship between the chief conductor and the business director of any top orchestra. By mastering these challenges, the Concertgebouw Orchestra has become an enduring institution.

\section{An Auspicious Beginning}

The early decades of the Concertgebouw Orchestra make for a compelling story of legendary chief conductors and a superior concert hall. ${ }^{1}$ In the late 1880s, a new music temple with unique acoustics was built on the southern edge of Amsterdam. It was founded and funded by six wealthy citizens-a lawyer, an equity trader, a banker, a cotton trader, a wine merchant and an attorney-who thought the time was ripe for the city to boast an ambitious, high-performing orchestra and a concert hall to match it. To this effect, they invested part of their private fortunes, earned in the Dutch East Indies and on the Amsterdam stock exchange, and founded the Concertgebouw Ltd. They governed both building and orchestra, acting as the employer of its musicians and staff (until 1952). 
The Concertgebouw opened its doors in the Spring of 1888. Six months later, the Concertgebouw Orchestra staged its first performance. Violinist, conductor and composer Willem Kes was the first permanent chief conductor and artistic leader of the orchestra. He introduced a broad repertoire, including contemporary orchestral music, to the Amsterdam audience and instilled a culture of disciplined musicianship within the orchestra. Under Kes's 7-year reign, the concertgoing public was socialized into the kind of concert etiquette that prevailed in other major centres of classical music around Europe, banning waiters, smoking and chatting during performances that had been customary around Amsterdam prior to the opening of the Concertgebouw. ${ }^{2}$

In 1895, Kes was succeeded by Willem Mengelberg-at just 24 years of age. In his extraordinary half-a-century reign as chief conductor and leader of the orchestra, Mengelberg turned the Orchestra into a toptier musical institution. Craving for perfection, Mengelberg transformed peripheral and pedestrian Amsterdam into an internationally respected centre of classical music on par with traditional strongholds such as Berlin and Vienna. His music, portions of which have been recorded, stood out by compelling interpretations rooted in the architecture of the compositions. Especially striking were Mengelberg's engaging style of conducting, the blending of the instruments, the extraordinary rhythmic precision, and his strongly developed sense for detail and transparent orchestral sound (Zwart 1999).

\section{Institution-Building Leadership}

The authoritarian Mengelberg turned the orchestra into a highly disciplined and cohesive unit, thanks to a rigorous selection of orchestra musicians and uncompromising performance expectations. Endless rehearsals lifted the orchestra to an ever-higher level. Film footage shows how he conducted: with radiant energy, demonstrating a clear and demonstrative baton technique (Bowen and Holden 2005: 127).

Mengelberg struck a judicious balance between devoting much attention to monumental and iconic works of classical music such as Bach's Matthäus-Passion and the avant-garde of contemporary composers, such as Mahler, Richard Strauss and Schönberg. Mengelberg's commitment to performing both iconic and emerging composers gave the orchestra its distinctive character and shaped its size and staffing. Mengelberg invited conducting composers to Amsterdam, such as Debussy, Grieg 
and Schönberg. Furthermore, he brought works of Dutch composers such as Diepenbrock and Dopper to the Amsterdam audience. The musicians' curiosity and commitment in performing lesser-known pieces and composers contributed to the orchestra's much-lauded chameleonic character.

His close ties with living composers helped shape the orchestra's distinctive character as both guardian and modernizer of classical music. His friendship with leading contemporary international composers such as Gustav Mahler and Richard Strauss proved an artistic asset. Both regularly came to Amsterdam to conduct their own works, as Mengelberg vigorously championed their music. Mahler considered the Netherlands his second cultural homeland after his native Austria. The acoustics of the Concertgebouw building were ideal for this late Romantic repertoire. A grateful Strauss dedicated his symphonic poem Ein Heldenleben to Mengelberg and the Orchestra.

Quality control in selection and retention of musicians was and remains a cornerstone of the Concertgebouw Orchestra's quality and reputation. The audition process originally set up by Mengelberg and evolving further under his successors boils down to a big knockout competition-with the musician coming in and playing behind a screen to ensure the influence of considerations concerning gender, ethnicity, age and appearance. Only one per cent of the candidates end up in the Orchestra. The process is nerve-wracking for the musicians being auditioned. Auditioning successfully requires a complete fusion of musician, music and instrument. The difference between good and outstanding is small but critical and the jury is extremely selective. A vacancy remains unfilled until someone is found who has the desired level. Until then, the orchestra will fall back on substitutes. Once in the seat, the musician must display a sufficiently strong personality, yet prove flexible and able to adapt in what is a demanding job involving ceaseless study, rehearsal, performances, travel, recordings, meetings with sponsors and the need to 'get along' in a community of precocious talents. The musicians must sacrifice economic comfort for artistic integrity: they earn on average 35\% less than their colleagues in other top orchestras.

Part of the Orchestra's reputation for the vigilance and adaptability of its musicians stemmed from an unexpected quarter: the peculiar acoustics of the Concertgebouw. On the concert stage, musicians were not seated particularly near to each other and could not hear each other very well (and this is still the case today). Therefore, they were compelled to listen 
very intently during play. This bred a level of concentration and alertness that was second nature and became a source of the young orchestra's growing reputation (Ferwerda 2013: 127).

The creation of the orchestra had occurred under a lucky star. The economic growth at the end of the nineteenth century was a major contributing factor. Yet financing the two-pronged endeavourthe building and the orchestra from scratch-entirely with private money proved challenging. From the 1910s onwards, first municipal and then national government funding was required. In return for the subsidies, government funders demanded subscription concerts as well as 'people's concerts' for music lovers who were less well-off. Both types of concerts required the orchestra to diversify its programming and further broaden its repertoire to cater to the tastes of a broader public.

Its public stature increased thanks to the touring of major concert halls in several European countries, starting in 1895, and thanks to its growing body of recordings - initially released on $78 \mathrm{rpm}$ records. International tours and recordings reinforced each other in the orchestra's quest for artistic prestige. In sum, within two decades after its founding, the orchestra could pride itself on a distinct identity, a highly rated competence and a fast-growing international reputation. The latter found expression in endorsements from members of the royal family, ministers, musicologists and composers from across Europe. The daily La Libre Belgique wrote in 1926 that 'the Concertgebouw Orchestra, together with the Vienna Philharmonic Orchestra, has mastery over the symphonic world' (Bottenheim 1950: 81).

The Mahler festival, organized in $1919 / 1920$ on the occasion of Mengelberg's 25th anniversary as chief conductor, formed a first apotheosis of the orchestra's ascent. It was not just an artistic highlight in the life of the building and the orchestra: with musicians from around Europe participating in the proceedings it became somewhat of a cultural peace conference, reuniting key players from Germany and France who had been on opposite sides of the Great War and had barely interacted since.

As the institution-building leader who had brought the orchestra up to world class, Mengelberg became a revered figure. As his fame spread, he made a series of high-profile guest appearances throughout eastern and western Europe and the United States, with an important side engagement as principal conductor of the New York Philharmonic Orchestra between 1922 and 1930 (Bowen and Holden 2005: 126). The second 
half of Mengelberg's career took a darker turn, getting hamstrung by fiscal and financial malaise and eventually ruined by his pro-German attitude and behaviour during the German occupation of the Netherlands during World War II. The former folk hero fell from grace after the end of the war and was no longer allowed to conduct in the Netherlands. Until his death in 1951 he lived a reclusive life in Switzerland, feeling banished and misunderstood (Zwart 2019).

\section{Tensions and Conflicts}

Behind the façade of the ostensibly seamless upward trajectory of the orchestra, significant tensions occasionally flared up. Firstly, there was the uneasy duopoly-common in many arts organizations-between the Chief Conductor and the Business Director, each representing a particular set of values and priorities within the orchestra's system. As early as 1902/1903 a power struggle took place between Mengelberg and business director (and previously a horn-playing member of the orchestra) Willem Hutschenruyter. This so-called 'Concertgebouw conflict' took place against the background of growing disgruntlement of the musicians about the great difference in salary between themselves and the conductor, who earned eight times as much as they did. It evolved around four issues: the position of the orchestra vis-à-vis the board of the Concertgebouw Ltd. that owned and operated both the building and the orchestra; the position of the orchestra vis-à-vis the chief conductor; the position of the business director within the orchestra-conductor force field; and, perhaps most important of all, Mengelberg's dictatorial behaviour towards the musicians (Samama 1988: 20-21). All parties made their complaints known to the board. Emotions ran high. The board sided with the chief conductor; the business director left and the orchestra had to cop it.

Notwithstanding - or perhaps as a response to-Mengelberg's long reign characterized by autocratic leadership, the orchestra's musicians developed a remarkable democratic self-consciousness. In 1915, they founded the Association 'Het Concertgebouworchest' (sic) in order to promote their interests with the board of the Concertgebouw and the chief conductor. Meanwhile in the 1930s, history repeated itself when conductor Mengelberg came into conflict with another business director, his namesake and distant relative Rudolf Mengelberg. As far as the conductor was concerned, Rudolf Mengelberg was to have position nor 
title on a par with his own stature, but nevertheless was expected to solve all the orchestra's organizational problems, including financial setbacks (Zwart 2016: 342). The director stood his ground and demanded to be given a suitable level of authority. This time, the conductor backed down and the board retained the director.

Secondly, almost from day one there were financial troubles. This should not come as a surprise; many cultural institutions suffer from them. American economists William Baumol and William G. Bowen made a connection between expenses of performing arts institutions (ballet, dance, music, theatre) and technological progress, which in most economic sectors boosts productivity. Orchestral labour productivity hardly rises. To perform a Mahler symphony, a certain number of musicians and a certain amount of time are needed. Playing faster with fewer musicians is not an option. Expenses in the labour-intensive orchestra world rise faster than in market-oriented sectors which have substantial possibilities to boost productivity. The consequence of this is a 'cost disease' which will inevitably cause budgetary problems, though orchestras such as André Rieu's that confine themselves to highly popular niches within orchestral music may at times beat the odds (Koopman 2018: 231-233).

In Amsterdam, the orchestra's private founders were faced with refinancing challenges and budget overruns. As maintenance costs of the building increased and wages of musicians and the chief conductor rose, it became more difficult to stay in the black, which was reflected in the patterns of patronage. In the decade following 1910, the traditional patronage proved insufficient to cover the costs. Public funding in the form of subsidies from the city and the state became a necessity, but with it came another set of actors whose views had to be taken into account in charting the course of the orchestra and rendering account of how the public's money was being spent.

Thirdly, the relation between the chief conductor and the business director had become an endemic source of tension. From day one, the regents of the building had given the chief conductor a very wide berth. This model regularly caused tensions involving Mengelberg and his successors and their business director counterparts. Given the fact that the board had few levers at its disposal to diffuse these tensions, conflicts could easily spin out of control. The demarcation of tasks and responsibilities was blurred. The director was supposed to implement decisions of the board and focus on administrative tasks. In consultation with the 
board he had to find a balance between the artistic mission zealously pursued and defended by the chief conductor and the personal, financial and organizational possibilities of the institution.

A cultural institution like the Amsterdam Orchestra can thus be deconstructed in various organizational units (Orchestra, building, commerce). Each of these units is represented by what Selznick (1957) referred to as administrative elites. An institution can only move forward and stay true to its founding mission if these elites find a way to work together. Institutional leadership is effective if it becomes collective leadership. In the remainder of this chapter, we will see that institutional balance is both jeopardized and achieved by these administrative elites.

\section{Post-War Consolidation: \\ Towards SElF-Governance}

The Second World War had a major impact on the institution. During the war years, both the building and the Orchestra benefited from the German occupier's expansive culture funding. Budgets had grown exponentially in 1940-1944, especially in the music sector. Post-war culture ministers stuck to this budget, even stretching it further.

At the same time, the Orchestra's wartime choices scarred its reputation. The military authority and the Ereraad voor Muziek, a post-war purging body, assessed that the board, the artistic management and the orchestra had done too little to resist the assault on its music by the German occupier. The government had expected a stronger sense of responsibility. Conductor Mengelberg was banned from ever conducting again in the Netherlands because of his compliant attitude towards the occupation. His intended successor Van Beinum was reprimanded and Rudolf Mengelberg was suspended as a director of the Concertgebouw for two years. Thirteen of the sixteen Jewish members of the orchestra who had been fired in 1941 had survived the war and returned to the orchestra.

Van Beinum eventually did take over the baton from Mengelberg. Using a more democratic leadership style than Mengelberg, Van Beinum succeeded in re-energizing the musicians and steering the orchestra back to public popularity, although not without significant hiccups. When experiencing a period of ill health he was obliged to hand over the baton to a guest conductor. The job was given to Paul van Kempen who was controversial because of his musical activities in Germany during the 
Second World War. Such a tainted past was extremely sensitive shortly after the war, when right in front of the Concertgebouw, there were still German bunkers. A fierce row erupted, including major protest actions outside the concert hall that even made it into The New York Times.

The uproar reopened a fault line in the governance of the institution. The musicians had become tired of the paternalistic style of the regents of the building, who under the existing governance structure could unilaterally set wages and hire and fire conductors and business directors. The regents were businessmen, and the musicians felt that the orchestra's artistic and organizational interests were held back by the regents' inclination to put the running of the building first and that of the orchestra second. They wanted to escape this straightjacket.

The quest for autonomy of the orchestra musicians and the political support for this ambition among the Amsterdam city council and part of the press had grown to such an extent that the unrest could no longer be squelched. The conflict became public in 1950, dragged on for many months, regularly creating headlines and triggering passionate political debates. Eventually, a solution was reached that involved a new set of arrangements between four parties: the ministry of Education, Arts and Sciences, the city of Amsterdam; the Concertgebouw Ltd.; and the Concertgebouw Orchestra, which was now acknowledged as a separate entity for the first time. In 1951, a direct relationship was created between the two governments and the orchestra, which meant that the subsidies no longer flowed via the Concertgebouw Ltd. In 1954, after a transition phase, a permanent foundation was established to be at the helm of the governance of the orchestra. Day-to-day management was put into the hands of a triumvirate: the Chief Conductor and a 2-person executive consisting of an artistic and a business director.

Though governance and revenue streams of building and orchestra had been decoupled, the Concertgebouw building remained the namesake and sound chamber of the Orchestra. The Concertgebouw Ltd. remained its landlord and service provider-being the owner/operator of the large instruments and the music library as well as the party handling the Orchestra's financial and subscriptions administration on a fee-forservice basis. Having lost government subsidies (which now went entirely to the Orchestra), the Concertgebouw building got into dire straits financially, causing the building to slide into a state of disrepair in the 1950s. Climate control suffered. In winter, people would turn up their collars or wear their coats and scarves. In summer, temperatures could surge and 
the windows at the top of the hall were opened, producing a downdraft over audience and orchestra members. Strings players' shoulders and arms hurt, wind instrument players struggled with condensation, harps had to be retuned (Koopman and Berkhout 2015: 26).

The new governance structure meant a new beginning for the Orchestra. The founding document of the newly independent Orchestra states: 'The purpose of the foundation is to promote the Dutch music culture by means of the conservation and development of the Concertgebouw Orchestra and by staging music performances by this orchestra, using all the legal purposes serving this goal'. This formula remains valid today. $^{3}$

With the separation, the Orchestra gained autonomy. A form of self-governance was introduced. The Foundation Royal Concertgebouw Orchestra employs the staff and musicians, most of whom are members of the aforementioned Association. Three members of its board are also member of the foundation board and are thus directly involved in all board decisions. The orchestra's artistic and business directors-who are named by the foundation board and may not be a member of the Association-interact with musicians on all levels. Artistic policy is determined by the Artistic Council (Artistiek Beraad) which includes the chief conductor, the artistic leader and representatives of the management and the orchestra.

It seems, as one former director once sighed, that everybody is forever evaluating everybody else at the orchestra. At times, this has certainly bred conflicts, slowing down decision-making and causing a degree of inertia. But this adversarial process also helped the administrative elites to find the required balance that a cultural institution under pressure so badly needs.

\section{Dealing with New Maestros}

Within any orchestra, the margin between order and chaos is small. Top orchestras need strong leadership. But a chief conductor has to earn and then use the hard-gained authority to imbue the orchestra with a musical vision and equip it to deliver on that vision.

In many ways, the leadership style of Mengelberg's post-war successors Eduard van Beinum (1945-1959) and Bernard Haitink (1963-1988) was refreshing after more than half a century of Mengelberg's authoritarian leadership. Both chose to give the musicians room to develop themselves and demonstrate their skills. And unlike Mengelberg, both were adverse 
to snobbery. The drawback of Van Beinum's personable, informal style was that it might open the door to a decline in the discipline instilled by Mengelberg and which had served the orchestra well. His term as a chief conductor ended abruptly when died of a heart attack during a rehearsal, not even 60 years old.

His legacy was soon eclipsed by Haitink, who became the stand-out conductor of the post-war orchestra. He took up the position when he was in his early thirties, and was initially seconded by the experienced German conductor Eugen Jochum. His early period with the orchestra was anything but easy. Originally trained as a violin player and relatively inexperienced as a conductor, he had to become an authority figure for an orchestra whose veteran musicians had played under the great Mengelberg and had internalized his style and standards. It was a hard grind, but his dedication and technique helped win them over.

He was helped along by demographic change. Just as the young Haitink was gaining some authority with the group, a watershed generational change occurred. The old guard gradually made way for a younger cohort that brought the spirit of the roaring sixties into the Concertgebouw. They no longer took the power of authority figures for granted, and were wont to argue with conductor and directors every step of the way. Yet, within the orchestral world with its internal focus, where in the end one single man decides, a more democratic culture is difficult to instil.

Indeed, initiatives and innovations not advocated for or at least condoned by the chief conductor were therefore bound to have a hard time. For example, the energetic post-war orchestra director Piet Heuwekemeijer had a vision of a large pool of musicians from which he could form a symphonic core as well as a chamber orchestra and several smaller ensembles. In his view, musicians could perform a broad repertoire that way.

Heuwekemeijer, who had played the violin in the Orchestra in the past, sought to revive this vision, which he had originally developed during the last years of the war. But his ideas, however visionary, went too far for Haitink and part of the orchestra. They feared his plan might damage the orchestral sound crafted under Mengelberg. In addition, the musicians also anticipated logistical and practical obstacles. The board eventually sided with the chief conductor-as it had done during the notorious Concertgebouw clash of 1903/1904. Another director bit the dust: Heuwekemeijer left. 
The emerging new culture of classical music not only was a divisive element internally, it also prompted major criticism from the outside world. Haitink was not neglecting the new music, but gave it less attention than his 'progressive' critics desired, notwithstanding his frequent performances of music of moderate modern and sometimes less moderate modern contemporaries. Five young composers demanded that the orchestra's management appoint another conductor alongside Haitink, who was to be specialized in new music. In their eyes, this expertthey favoured the charismatic Bruno Maderna-would be the spiritual successor of Mengelberg, who in his day had introduced the musical innovators of the era, such as Mahler and Richard Straus, to the orchestra. In late 1969, the rebelling composers disrupted a concert with rattles, horns and the occasional flute. Some concertgoers cracked nuts. But the protests failed to achieve their objective. Artistic Director Marius Flothuis protected Haitink and the orchestra board chose to weather the onslaught of the angry young men.

Haitink would evolve into a major conductor of global stature. He spoke about his predecessor Van Beinum respectfully, built a broad repertoire without precedent and was acclaimed for his interpretations, which besides an intense musicality displayed both respect for the score as well as sensitivity for the nature of the orchestra. He thus developed his own sound signature. He succeeded in maintaining and exploiting the orchestra's Mahler tradition initiated by Mengelberg in an inimitable way, reaching millions with countless recordings, intercontinental tours to the United States and Japan and Eurovision Christmas matinee performances. Besides his commission at the Concertgebouw Orchestra he pursued a successful second career in England, not only as an orchestra leader but also as an opera conductor.

An austere man, his professional persona was far removed from the jet-setting prima donna type modelled by his illustrious contemporaries Herbert von Karajan and Leonard Bernstein. Under his leadership, the Concertgebouw Orchestra once again became a close-knit team, inspired by Haitink and eager to perform. Haitink, in turn, was inspired by the input of solo instrumentalists within the orchestra. At times, this brought about magical moments during concerts in which the well-attuned musicians felt exactly what others wanted or would do. A feeling of radical unity - an unio mystica (Zijderveld 1998: 21; Bekaert et al. 2016: 21).

After the rise of the ensemble culture in the 1960s, the 1980s again brought new changes impacting symphonic orchestras' fortunes. The 
shelf life of chief conductors began to diminish. A term of a quarter of a century, like Haitink or Von Karajan had served, became a thing of the past. Influenced by the trend of globalization, an army of guest conductors travelled around the world with their one-night stands, generally drawing on a limited repertoire. Long-serving chief conductors with an exceptionally large repertoire, like Haitink, became a rarity. Guest conductors with a specific focus or specific skills were brought in, such as Nikolaus Harnoncourt for the performance of old music.

The orchestra's management failed to communicate its increasing engagements with guest conductors clearly to Haitink, who himself worked in England part of the time. A feeling of discomfort and a level of distrust of the Concertgebouw Orchestra's management emerged inside Haitink, and continued to fester ever after (Hagmann and Singer 2019: 22-23, 58-59). The arrival of Harnoncourt imposed limitations on Haitink's repertoire. He had to remove works by Bach, Haydn and Mozart from his programs. This, in addition to the fact that the orchestra's musical director Van Royen had set his eye on the young Italian conductor Riccardo Chailly as Haitink's successor and had unveiled this early on, set the stage for a protracted, tense and emotional final period of Haitink's tenure. Dismissal letters were written and withdrawn. A whirlwind of rumours occurred and accusations were widely reported in the media.

In the final phase, Haitink only interacted with the orchestra inspector, the manager of the podium staff who operates in the bowels of the building. The orchestra's audience base was incensed by the drama and so were the main subsidy providers. The national government's arts ministers Elco Brinkman urged the parties publicly to cool it, as did Amsterdam mayor Ed van Thijn. But there was no backing down. Haitink left full of resentment, disillusioned by the politics of the orchestra's management, an abrupt farewell of a chief conductor who had succeeded in ensuring the post-war orchestra retained its world-class status.

\section{Balancing Artistic and Commercial Interests}

During the reign of Haitink's successor Riccardo Chailly (1988-2004), tensions between commercial and artistic interests were stretched to the limit. The post-war orchestra had become strongly subsidy-driven. As long as the state and the city's money continued to flow in, the orchestra contentedly accepted it without thinking of alternative funding. When 
faced with fiscal crisis in the early 1980s, Dutch authorities began to curb spending drastically. The ensuing subsidy cuts hit the orchestra hard. Contributions from sponsors and donors were needed to save the orchestra from bankruptcy. In the foundation board, thoughtful lawyers and public administrators made way for entrepreneurs and executives from the financial world. They knew how to bind companies and banks to the Orchestra.

Business Director Willem Wijnbergen, who in 1992 had joined the orchestra following a career at Procter \& Gamble, set about 'cleaning up' what he considered to be its dusty and tired back office. He also pursued a strong foreign presence for the orchestra, intensifying its international touring commitments. By virtue of higher fees paid by foreign concert halls and numerous CD recordings, he managed to reduce the deficit on the orchestra's budget. The orchestra remained dependent on subsidies but now for slightly less than half of its annual budget-around 29 million euros today. Over time, the financial reserve built by Wijnbergen in those years laid the foundation for an endowment whose revenues were used for the purchase of expensive music instruments and the pursuit of special projects. ${ }^{4}$

At this time, the Concertgebouw building's finances were in better shape than those of the orchestra. Its Director, Martijn Sanders, who had worked in the movie theatre business, had managed to win the support of top businesses, authorities and individuals for the ailing institution with an American-style fundraising campaign. Twenty million euros were spent to put the sagging building on a new foundation, modernize it and add an extension, a new cellar and modern technical installations. The concerts continued during the renovations.

The building's executive board pursued event programming policies that gave more airtime to other musical acts. It featured a series of 'World famous symphonic orchestras'. It also set up an endowment to benefit the preservation of the monumental building as well as projects in the field of music education and involvement. One thing remained unchanged: the endemic tension between the operating logic of the building and that of the orchestra. For example, legal wrangling regarding the settlement of the division of the assets between building and orchestra continued four decades after the 1951 act of separation between the two.

The Orchestra's artistic integrity remained intact. The arrival of Riccardo Chailly in 1988 initially brought in a new era with much late Romantic, twentieth century and contemporary work. Chailly-in his 
thirties and the first foreign-born chief conductor-was a mediagenic maestro who eagerly positioned himself in the tradition of Mengelberg. He sharpened the orchestra's artistic profile. His choices forced the orchestra to study many complex parts within a short period of time. On top of that, Chailly-a control freak and precision fanatic-rehearsed in a stricter manner than Haitink had done, leaving the musicians less room for personal input that they had become accustomed to.

\section{A New Lease on Life}

Tensions between administrative elites kept making victims. Wijnbergen's commercial approach eventually got him into strife with the wellrespected Artistic Director Jan Zekveld who had joined the orchestra in 1993 but then left prematurely and to considerable media and political fanfare in 1996. One year later, then-state secretary of Culture Aad Nuis warned of a downward spiral in which the orchestra produced an ever-rising number of CDs geared to attract prestige abroad, and trading its artistic excellence for a safer 'middle of the road' repertoire that was required to sell CDs. Wijnbergen saw the writing on the wall and resigned in 1998.

He was succeeded in 1998 by the experienced Orchestra Director Jan Willem Loot. Upon his arrival, Loot pioneered a new management model. The co-equal triumvirate model with a chief conductor, a business and an artistic director had outlasted its usefulness, with more and more unresolved conflicts between them landing on the desks of the orchestra's foundation's board. Under the new model, the executive board became a triumvirate, yet with Loot as a clear primus inter pares as general managing director, to be seconded and supported by an artistic and a business director. In relation to the chief conductor, he opted for a form of shared, complementary leadership: the managing director and the chief conductor became equal partners.

Entrepreneurship soon flourished. The Orchestra relied on three complementary forms of patronage - traditional patronage, considerable levels of public funding and corporate sponsorship. Managing Director Loot caused a stir with the creation of a dedicated new record label for the orchestra. ${ }^{5}$ Loot also invested in a concert series with an adventurous repertoire, which attracted a lot of attention. His equally experienced successor Jan Raes likewise was unafraid to take risks. He professionalized the in-house orchestral academy for emerging talent, raised the number 
of family concerts, educational apps, interdisciplinary concert formulas in cooperation with other Amsterdam art institutions and partnerships with primary and secondary education. These initiatives helped to preserve a balance between the Orchestra's financial needs and its institutional integrity.

But it was an uneasy balance, which chief conductors not always found easy to handle. Chailly, a classic prima donna who had already struggled with the Amsterdam orchestral democracy upon his arrival, found it especially difficult. Chailly's leadership style gradually prompted rising irritation and increasing levels of sick leave among the orchestra musicians. In the middle of the 1990s, there was criticism of Chailly's interpretations of French and late Romantic music, among which that of Mahler-the historical trademark of the orchestra. Yet there was also a kind of gritted respect for the ease with which he conducted the modern repertoire and opera music. But the general atmosphere in and around the orchestra left much to be desired at this time. Disappointed by what he saw as disrespectful machinations, Chailly moved to Leipzig in 2004-yet another painful parting of a long-serving chief conductor.

With his successor Jansons, the partnership model proved very effective. The 61-year-old Latvian, the first incoming chief conductor with decades of world-class experience under his belt, turned out to be the mature and visionary orchestra leader everybody wanted. In his view, the chief conductor is someone who takes care of his orchestra members while guarding his artistic and human principles. Setting extremely high standards in recruitment and retention, he was at the same time deeply respected within the Orchestra for his empathy and professionalism. One concern was the fact that Jansons-like Van Beinum-had a heart condition, was under permanent medical supervision and was sometimes absent.

Under Jansons, the orchestra flourished artistically. He questioned nearly everything. Following a day of rehearsing in a certain tempo, he could easily surprise the Orchestra in the evening by opting for another tempo at the concert. This was in sharp contrast with Chailly, who rarely deviated from the rehearsed tempo. Jansons could master almost every style. He extended the Orchestra's repertoire, fitting well his notion of the 'universal orchestra'. Jansons also upheld the Amsterdam Mahler tradition. In his opinion, few composers were able to express such an unparalleled spectrum of moods and thoughts, from drama and joy to sarcasm and hatred. 
In 2013, the orchestra went on a world tour, also visiting Africa and Australia. The documentary of this tour was a major hit on Dutch television, introducing the Orchestra to a large audience and turning its musicians into public personalities. Between 2016 and 2018, the orchestra visited all EU member states. It performed together with local youth orchestras. Raes also initiated a European orchestra project for young talent. Moreover, in 2018 he signed for the acquisition and renovation of the privately financed RCO House. The new accommodation combined staff offices, rehearsal studios and a small concert hall for chamber music- $\mathrm{a} € 10$ million project.

Jansons succeeded in firmly embedding the orchestra within the highest levels of the symphonic premier league. In 2008, British magazine Gramophone declared the Concertgebouw Orchestra best in the world, based on a survey among international music critics associated with among others Die Presse, Le Monde and The New Yorker. Loved by the orchestra, the critics and the public, he left amicably in 2015 .

\section{Thriving Despite Turbulence:}

\section{A Resilient Institution}

A top orchestra reaches an institutional equilibrium when it reaches artistic excellence within robust budgetary boundaries while answering to the notions of external critics with regard to the nature of a top orchestra (Tovey 2003: 214). Scottish moral philosopher Alasdair MacIntyre sees a connection between practices and institutions (MacIntyre 2007: 218226). Respect for traditions - conceived of by MacIntyre (2007: 257) as 'embodying continuities of conflict'-is a sine qua non for artistic labour. ${ }^{6}$ To enter a practice is to enter into a relationship not only with one's contemporary practitioners, but also with those who have preceded us in the practice, particularly those whose achievements extended the reach of the practice to its present point.

Projecting MacIntyre's philosophy onto the Orchestra, we recognize the everlasting battle between artistic aspirations and commercial interests; between traditions, meanings and values and techniques, processes and procedures - in short, between substantial and functional rationality. When artistic goals are pursued so strongly as to dwarf commercial considerations an orchestra can rapidly drift into dire straits. Conversely, when commercialism reigns, safe mainstream programming may ensue and compromise the artistic stature of an orchestra. 
Balance remains critical. Institutions must acquire money and other material goods; they are structured in terms of power and status, and they distribute money, power and status as rewards. Nor could they do otherwise if they are to sustain the valued, artistic practices of which they are the bearers. For no practices can survive for any length of time when institutions cannot sustain them.

Navigating these competing values has proven challenging for the Concertgebouw Orchestra. As we have seen, it encountered a crisis of sorts nearly every decade in its existence, usually stemming from escalating conflicts in negotiating its two embedded fault lines: building v. orchestra, artistry v. business. Its initial governance was rooted in paternalism and autocracy. Over time a system of commissions, decision rights and consultation structures evolved that ensured the success of the Orchestra as an institution. Institutional resilience did not only spring from the leadership of chief conductors and business directors. It also resides with the members of the Orchestra-one hundred and twenty strong personalities submitting themselves to one entity, assuming shared responsibility for maintaining the Orchestra's values and standards of excellence.

This chapter shows that organizational design is also critically important for an institution. During the 1980s/1990s, the Orchestra's virtuous cycle came perilously close to sliding into a vicious cycle of decline. The dyadic structure of an artistic and a business director that was in place at that time failed to resolve the inherent tensions between artistic ambitions and commercial imperatives; it even began to undermine effective governance. Business Director Wijnbergen was focused on generating income through numerous foreign concerts and an extensive program of CD recordings, while Artistic Director Zekveld was bent on presenting the demanding Amsterdam audience with the most magnificent (and expensive) billings. The duopoly model lacked a primus inter pares with the authority to restrain both parties' behaviour. There were simply too many conflicts that paralyzed the organization and risked rendering it stagnant.

It was not until the orchestra's governance structure was changed and long-serving general managing directors with broad authority were appointed (Loot, 1998-2008, and Raes, 2008-2019) at the top of what was now a triad that a mature and balanced approach began to emerge. Within this more stable governance framework, artistic dreams could be spun and musical beauty could be created without losing sight of the precarious business realities. The subtle balance between home and 
abroad was maintained: the Concertgebouw Orchestra remains both an Amsterdam orchestra and a global player.

What has remained is the Orchestra's musical DNA: its velvet string sound, the golden sound of the brass, the personal timbre of the woodwind players and the stylistic flexibility. This DNA has been firmly embedded within the organization, is difficult to copy and apparently not dependent on one or a few visionary individuals. The metaphor of the Ship of Theseus in ancient Athens comes to mind. Each rotting plank was being replaced and as the years went by, ultimately not a single plank was original. The ship nevertheless remained, in a sense, Theseus' ship. With some luck, an attentive listener can sometimes hear remnants of Mengelberg's orchestral sound in today's orchestra, even though none of the original musicians play in the orchestra today, and there are musicians from more than twenty nationalities. It is the mystery of the creative process.

\section{Maintaining Balance in the Face of Future Challenges}

The symphony orchestra is one of the great cultural achievements of European civilization. It is also one of Europe's most significant cultural exports. What began as relatively small collections of musicians in the courts of central Europe in the seventeenth century has not only grown in size but also achieved wide geographical spread. Institutionalization of these orchestras is based on a delicate compromise between financial needs and basic artistic principles that motivate a community of musicians and help to win the respect of the public.

Leadership clearly matters in bringing about institutionalization. The Concertgebouw Orchestra's musical DNA and international reputation builds on Mengelberg's conductorship. He laid the foundation for the Mahler tradition, an interactive practice that continues to be maintained and exploited today. The orchestra leader made ample use of the freedom granted to him by the Concertgebouw's culture regents. This regularly caused tensions between conductor and director, and among his successors. This model, a recurring rupture, proved a fruitful basis for an ever-renewing and successful orchestra.

The Concertgebouw Orchestra will have to find an answer to the changing audience demographic and preferences. This does not mean it needs to bring in laser beams and smoke machines or perform one 
blockbuster after another to please the audience. The solution might be found within the orchestra's own history. Mengelberg made friends with composing contemporaries. The current orchestra could reach out to leading twenty-first-century composers who have breached into younger and bigger audiences, such as Christiaan Richter.

Tensions will always remain. Financially, the Orchestra is always skating on thin ice. The Orchestra most likely will remain dependent on sponsor and donor contributions. So far, this has not damaged its artistic autonomy and there are no indications that its decline is imminent. But institutional balance between artistic necessities and financial needs is essential. Competing orchestras in Germany, Austria or the United States are always tugging on Amsterdam's top talents. Moreover, for financial reasons, international top talent looking for an orchestra position is likely to think twice before auditioning in Amsterdam, where one has to accept substantially lower salaries. Artistic standards and institutional integrity must be defended. The Orchestra is too important to be allowed to subside into cultural antiquity for an ever-shrinking group of interested music historians (Cottrell2005: 251, 264).

\section{Questions FOR Discussion}

1. Maintaining a balance between artistic vision and financial realities is a central challenge for any cultural organization. What can be learned from the Concertgebouw Orchestra's institutional journey?

2. What lessons can be drawn from the Concertgebouw Orchestra's experiences in striving to balance 'museal' and the 'laboratory' functions that other cultural organizations might find useful?

3. How has the Concertgebouw Orchestra's authorizing environment evolved over time and how have these changes impact upon its institutional legitimacy?

4. The story of the Concertgebouw Orchestra is a story about organizational elites. What lessons can be learned that may be useful for the management of the various elites in an institution?

5. What key challenges to the value propositions and mission of cultural institutions exist at the present time? How might institutional leaders tackle them? 


\section{Notes}

1. Since 1988, the Concertgebouw Orchestra has the predicate Royal. Abroad, it uses the name Concertgebouw Orchestra.

2. He left after 7 years, joining the Scottish Orchestra in Glasgow which offered more artistic leeway and higher earnings.

3 . The meaning of the broad formulation 'music culture' remains unclear.

4. In the years until 2019 a total of 42 million euro's in donations was received.

5. Chailly had taken his contract with Decca with him to Leipzig.

6. Historians are more used to invented traditions - a term used by the British historian Eric Hobsbawm and his African colleague Terence O. Ranger to refer to the mythical historical stories used by for example nineteenthcentury nation states to provide themselves with impressive genealogies. They consider these stories of ancestry a form of 'false consciousness'. See Paul (2014: 74).

\section{REFERENCES}

Bekaert, X., Jonk, G., Wibbens, P., \& Raes, J. (2016). Iconic: How to Create a Virtuous Circle of Success. London, United Kindom: LID Publishing.

Bottenheim, S. (1950). Geschiedenis van het Concertgebouw (Vol. 3). Amsterdam, Netherlands: Joost van den Vondel.

Bowen, J. A., \& Holden, R. (2005). The central European tradition. In J. A. Bowen (Ed.), The Cambridge Companion to Conducting (pp. 114-133). Cambridge, United Kingdom: Cambridge University Press.

Cottrell, S. (2005). The future of the orchestra. In C. Lawson (Ed.), The Cambridge Companion to the Orchestra (pp. 251-264). Cambridge, United Kingdom: Cambridge University Press.

Ferwerda, H. (2013). Een uniek orkest. In M. Khalifa (Ed.), Bravo! 125 Het Concertgebouw en Koninklijk Concertgebouworkest (pp. 123-137). Amsterdam, Netherlands: Balans.

Hagmann, P., \& Singer, E. (2019). Bernard Haitink. 'Dirigieren ist ein Rätsel'. Gespräche und Essays. Kassel, Germany: Bärenreiter.

Koopman, B. (2018). Competentiestrijd in de Muziektempel. Een Zakelijke Geschiedenis van het Concertgebouw (Dissertation). Leiden University, Amsterdam, Netherlands: Prometheus.

Koopman, B., \& Berkhout, T. (2015). Achter de Schermen. Het Concertgebouworkest tussen Traditie en Vernieuwing. Amsterdam, Netherlands: Cossee.

MacIntyre, A. (2007 [1981]). After Virtue: A Study in Moral Theory. London, United Kingdom: Bloomsbury. 
Paul, H. (2014). Als het Verleden Trekt. Kernthema's in de Geschiedfilosofie. Amsterdam, Netherlands: Boom.

Samama, L. (1988). Willem Mengelberg de woelige jaren, 1895-1920. In H. J. Van Royen (Ed.), Historie en Kroniek van het Concertgebouw en het Concertgebouworkest (Vol. 1, pp. 97-148). Zutphen, Netherlands: Walburg Pers.

Selznick, P. (1957). Leadership in Administration: A Sociological Interpretation. New York, United States of America: Harper \& Row.

Tovey, B. (2003). The conductor as artistic director. In J. A. Bowen (Ed.), The Cambridge Companion to Conducting (pp. 203-219). Cambridge, United Kingdom: Cambridge University Press.

Van Putten, B. (2016, August 31). 'Meewiegen met Mahler'. Amsterdam, Netherlands: De Groene Amsterdammer.

Zijderveld, A. C. (1998 [1987]). De Samenleving als Schouwspel. Een Sociologisch Leer- en Leesboek. Maarssen, Netherlands: Elsevier/De Tijdstroom.

Zwart, F. (1999). Willem Mengelberg (1871-1951). Een Biografie 1871-1920. Amsterdam, Netherlands: Prometheus.

Zwart, F. (2016). Willem Mengelberg (1971-1951). Een Biografie 1920-1951. Amsterdam, Netherlands: Prometheus.

Zwart, F. (2019). Conductor Willem Mengelberg, 1871-1951: Acclaimed and Accused. Amsterdam, Netherlands: Amsterdam University Press.

Open Access This chapter is licensed under the terms of the Creative Commons Attribution 4.0 International License (http://creativecommons.org/licenses/ by $/ 4.0 /)$, which permits use, sharing, adaptation, distribution and reproduction in any medium or format, as long as you give appropriate credit to the original author(s) and the source, provide a link to the Creative Commons license and indicate if changes were made.

The images or other third party material in this chapter are included in the chapter's Creative Commons license, unless indicated otherwise in a credit line to the material. If material is not included in the chapter's Creative Commons license and your intended use is not permitted by statutory regulation or exceeds the permitted use, you will need to obtain permission directly from the copyright holder.

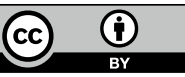

